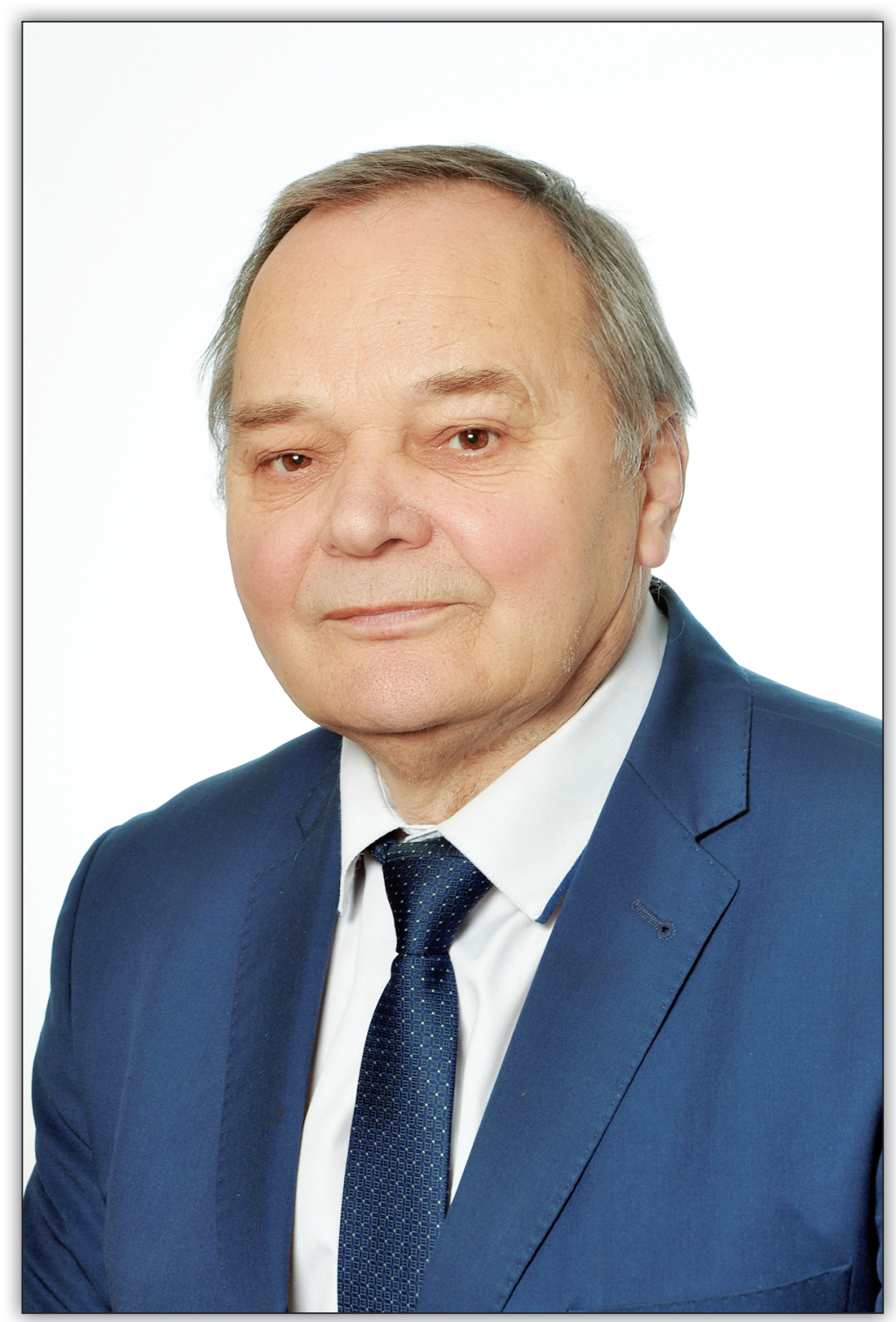

Profesor Feliks Czyżewski 



\section{PROFESOR FELIKS CZYŻEWSKI - UCZONY, SPOŁECZNIK, HONOROWY OBYWATEL WŁODAWY}

4 kwietnia 2019 roku Profesor Feliks Czyżewski, urodzony we wsi Jusaki-Zarzeka koło Łomaz, absolwent studiów polonistycznych na Uniwersytecie Marii Curie-Skłodowskiej w Lublinie, ukończył 70. rok swego życia. Jest to dostojny jubileusz, tym dostojniejszy, że właśnie w owym jubileuszowym dla prof. F. Czyżewskiego roku Rada Miejska Włodawy podjęła uchwałę o włączeniu Profesora w poczet swoich Honorowych Obywateli. Nie jest to zaszczyt, którym Rada obdziela zbyt często. W swojej historii po 1990 roku wyróżnienie to spotkało zaledwie siedem osób cieszących się powszechnym autorytetem, które bezinteresownie włożyły istotny wkład w rozwój miasta, przyczyniły się do jego rozsławienia poza granicami ziemi włodawskiej i Lubelszczyzny. Decyzją Rady Miejskiej do tego grona dołączył Pan Profesor Feliks Czyżewski, znakomity uczony, ceniony w Polsce i poza granicami naszego kraju, organizator życia naukowego i społecznego.

Tradycją jest, że z okazji tak podniosłej uroczystości przybliża się sylwetkę osoby wyróżnionej, najważniejsze jej dokonania na wszystkich płaszczyznach aktywności, a zwłaszcza te najistotniejsze dla regionu - dla Włodawy i ziemi włodawskiej. Dla mnie zaszczytem jest, że to właśnie ja mam możliwość wygłoszenia tej mowy. Przyjechałam z odległego Poznania, nie mam codziennych kontaktów z Profesorem, jednak moje zawodowe związki z Jubilatem są na tyle wielostronne i intensywne, że nie miałam wątpliwości, by przyjąć propozycję wygłoszenia laudacji zgłoszoną przez Towarzystwo Przyjaciół Ziemi Włodawskiej. Łączy mnie bowiem z Jubilatem wspólna dyscyplina naukowa - językoznawstwo diachroniczne i wspólny obszar badawczy - pogranicze polsko-wschodniosłowiańskie. Mieliśmy też wspólnego dla nas obojga mistrza - Profesora Władysława Kuraszkiewicza, wybitnego slawistę, włodawianina, którego miasto uhonorowało w 2009 roku, nadając jego imię rondu u zbiegu ulic Chełmskiej i Korolowskiej, członka Towarzystwa Przyjaciół Ziemi Włodawskiej; jego pamięć Profesor Czyżewski pielęg- 
nuje od lat, choćby przez inicjowanie wydarzeń naukowych i kulturalnych z rocznicowych okazji czy też przez publikowanie artykułów przybliżających czytelnikowi dorobek naukowy W. Kuraszkiewicza, zajmujący trwałe miejsce w polskiej nauce, szczególnie w slawistyce wschodniosłowiańskiej. Ponadto łączy mnie z Jubilatem współpraca akademicka Lublina i Poznania, uczestnictwo w tych samych wydarzeniach naukowych i społecznych; wreszcie łączy nas szczególne umiłowanie ziemi włodawskiej i szerzej - terenów nadbużańskich. Profesor Czyżewski z tym obszarem jest związany miejscem urodzenia, wykształcenia i pracy, ja przyjeżdżam tu corocznie przede wszystkim na organizowane przez Profesora lub z Jego inicjatywy wydarzenia naukowe, ale też przyjeżdżam z fascynacji tą krainą - jej przyrodą, a przede wszystkim ludźmi: życzliwymi, otwartymi, przyjaznymi. Moje refleksje z okazji obchodzonego jubileuszu mają też jeszcze jedno uzasadnienie. Takie mianowicie, że spojrzenie z dystansu, z perspektywy odległego Poznania pozwala ukazać Jubilata $\mathrm{w}$ innym, tu na miejscu może nie zawsze zauważalnym kontekście - jako człowieka, którego dokonania naukowe, organizacyjne, społeczne, a zwłaszcza Jego praca na rzecz rozsławienia ziemi włodawskiej i szerzej terenów nadbużańskich, mają wymiar ponadlokalny, są dostrzegane i odnotowywane w środowiskach akademickich jako ważne wydarzenia i dla nauki, i dla społeczności lokalnych, im to bowiem poświęca swój czas i twórczy wysiłek. Tę działalność Jubilata dostrzegamy i wysoko cenimy w Poznaniu, Łodzi, Warszawie, Krakowie, Toruniu i w innych środowiskach uniwersyteckich. Dlatego z wielkim uznaniem i radością przyjmujemy wniosek Towarzystwa Przyjaciół Ziemi Włodawskiej i podążającą za nim decyzję Rady Miasta Włodawy o przyznaniu Profesorowi Feliksowi Czyżewskiemu tytułu Honorowego Obywatela Włodawy, i to właśnie w roku, w którym obchodzi swoje siedemdziesięciolecie. Szacunek budzi to, że Towarzystwo Przyjaciół Ziemi Włodawskiej i władze miasta doceniły wieloletnie i wielopłaszczyznowe związki Jubilata z Włodawą i ziemią włodawską. Jestem przekonana, że nie tylko włodarze miasta i powiatu, ale i społeczność lokalna dostrzega i ceni wysiłki Jubilata na rzecz ich małej ojczyzny, a przyznanie godności Honorowego Obywatela Włodawy jest formą podziękowania i zachęty do dalszej dobrej współpracy, jak inaczej można bowiem zrozumieć słowa starosty włodawskiego, pana Wiesława Holaczuka, który napisał w dedykacji: ,[S]kładam wielkie podziękowania za dotychczasową współpracę i mam wielką nadzieję na dalszą współpracę. Dla mnie to wielki zaszczyt i honor wspierać Pana Profesora $\mathrm{w}$ wielu wyjątkowych zamierzeniach propagujących unikalne w skali światowej pogranicze wielu kultur [...] Jest Pan znakomitym Ambasadorem Ziemi Włodawskiej”. Pod tymi słowami Pana Starosty zapewne wszyscy podpisujemy się oburącz.

Profesor Czyżewski, od lat pracownik naukowo-dydaktyczny w Instytucie Filologii Słowiańskiej Uniwersytetu im. Marii Curie-Skłodowskiej 
w Lublinie, gdzie przeszedł całą ścieżkę awansu zawodowego od asystenta do profesora zwyczajnego i gdzie pełnił odpowiedzialne funkcje naukowe i organizacyjne - w 1998 roku został kierownikiem Zakładu Filologii Ukraińskiej, a w latach 2003-2013 był dyrektorem Instytutu Filologii Słowiańskiej, swoją pierwszą pracę zawodową, po skończonych studiach polonistycznych, podjął na ziemi włodawskiej, w Liceum Ogólnokształcącym w Wisznicach. Pracował tam w latach 1972-1975. Choć praca w Wisznicach trwała tylko kilka lat, dobrze się zapisał w pamięci wisznickiej społeczności i absolwentów szkoły. Świadectwem tego jest zorganizowany właśnie w wisznickiej szkole jubileusz 45-lecia pracy dydaktycznej i naukowej Profesora. Związki Jubilata z oświatą i dydaktyką ziemi włodawskiej to również stała od lat 70 . współpraca z nauczycielami Liceum Ogólnokształcącego we Włodawie, głównie z polonistami, a także uczestnictwo w międzyszkolnych zespołach humanistycznych, zasiadanie w jury konkursów, w których uczestniczą uczniowie szkół ziemi włodawskiej. Wychowankowie Profesora z wisznickiego liceum do dziś pracują na terenie powiatu włodawskiego.

Dla mnie jako dla przedstawicielki środowiska akademickiego wielkie znaczenie mają naukowe osiągnięcia Profesora Czyżewskiego, a Jego wkład w poznanie języka i kultury powiatu włodawskiego jest powszechnie znany i bardzo wysoko oceniany. Bo związki Profesora jako Uczonego z ziemią włodawską to przede wszystkim praca naukowa nad opisem mowy lokalnej ludności. W wyniku wieloletnich badań terenowych prowadzonych już w latach 70. XX wieku dotarł do mieszkańców 40 miejscowości, pozyskał ogromny materiał, liczący w sumie około 50 tys. zapisów form gwarowych od ponad 100 informatorów. Ponadto zapisał wiele ciągłych tekstów, pozwalających zarejestrować aktualną dla połowy XX wieku kulturę ludową ziemi włodawskiej. Prowadzone badania terenowe, spotkania z informatorami były świetnym wprowadzeniem w złożoność problematyki dialektologicznej, języka i kultury regionu włodawskiego. Tutaj, na ziemi włodawskiej, w tym „mateczniku języków" - jak to określał Profesor Stefan Warchoł, lubelski slawista - dzisiejszy Jubilat odnajdywał odpowiedzi na pytania dotyczące genezy procesów językowych ukraińszczyzny i polszczyzny. W trakcie owych badań poznawał też złożone problemy konfesyjne, etniczne i językowe ludu włodawskiego. Warto w tym kontekście wspomnieć, że ten kierunek prac Feliksa Czyżewskiego pozostaje $\mathrm{w}$ związku z wcześniejszymi badaniami pogranicza polsko-wschodniosłowiańskiego prowadzonymi przez Profesora Władysława Kuraszkiewicza. Wysoko cenionym efektem tych prac dzisiejszego Jubilata była już Jego rozprawa doktorska zatytułowana Gwary ludowe powiatu włodawskiego, obroniona w 1982 roku, zaś drukiem wydana w Lublinie w 1986 roku jako Atlas gwar polskich i ukraińskich okolic Włodawy. Książka doczekała się wielu bardzo pozytywnych recenzji zagranicznych i polskich, otrzymała też nagrodę Ministra Szkolnictwa Wyższego, a nasz mistrz, Profesor 
Władysław Kuraszkiewicz, tak pisał o Atlasie: „Atlas jako dzieło jednego autora imponuje solidnością wykonania kilkuletniej pracy w terenie, [...] rozmaitością treści zanotowanych elementów kultury ludowej”. Z kolei Profesor Janusz Rieger, pracownik Instytutu Słowianoznawstwa PAN, stwierdzał: „Autor wnosi cenny wkład do metodologii badań w zakresie dialektologii słowiańskiej, zestawiając dwa systemy językowe wielu wsi na znacznym obszarze, posługując się kartografią lingwistyczną".

Atlas gwar polskich $i$ ukrainskich okolic Włodawy to jednak niejedyny efekt prac badawczych dzisiejszego Jubilata nad kwestiami języka i kultury ziemi włodawskiej, południowo-wschodniego Podlasia, generalnie - pogranicza polsko-wschodniosłowiańskiego. Niejedyny efekt, ponieważ Profesor Czyżewski jest autorem około 200 pozycji naukowych, w tym kilku książek autorskich bądź współautorskich, z których większość dotyczy właśnie tych obszarów. Do tego dochodzą liczne monografie i księgi zbiorowe redagowane przez Profesora. Dorobek to ogromny, imponujący, o niezaprzeczalnym znaczeniu dla polskiej i światowej slawistyki. Dla przykładu tylko wymienię kilka prac najbliższych ziemi, na której się znajdujemy. A są to: Fonetyka i fonologia gwar polskich i ukraińskich poludniowo-wschodniego Podlasia (Lublin 1994) czy Polskie i ukraińskie teksty gwarowe ze wschodniej Lubelszczyzny (Lublin 1998; współautor Stefan Warchoł). Praca ta zasługuje na szczególną uwagę, jest to bowiem najpełniejsze i najbogatsze materiałowo i interpretacyjnie przedstawienie gwar polskich i ukraińskich funkcjonujących na pograniczu polsko-wschodniosłowiańskim. Jest to też jedyne tego typu opracowanie na gruncie dialektologii słowiańskiej, nie tylko polskiej. Bardzo ważna dla wiedzy o regionie jest też książka Antroponimia pogranicza polsko-wschodniostowiańskiego $w$ świetle inskrypcji nagrobnych, część 1: Stownik nazwisk (Lublin 2013). Jest to publikacja o dużej wadze naukowej, zawiera bowiem wiele nieznanych wcześniej faktów onomastycznych, a ponadto jest innowacyjna metodologicznie i precyzyjna warsztatowo. Inskrypcje nagrobne pogranicza polsko-ukraińskiego były przedmiotem badań w ramach kierowanego przez Profesora projektu badawczego o charakterze interdyscyplinarnym. Poza językoznawcami projekt gromadził historyków, kulturoznawców, etnografów i teologów. Zresztą to niejedyny transgraniczny projekt, którym kierował bądź w którym uczestniczył dzisiejszy Jubilat. Przypomnieć trzeba choćby polsko-ukraiński projekt Cmentarze po obu stronach Bugu (realizowany w latach 2013-2015). Mówiąc o ważnych dla regionu projektach, warto też przywołać nienależącą do nurtu lingwistycznego, który reprezentuje Jubilat, napisaną we współautorstwie ze Zbigniewem Fronczkiem i Arturem Sitką książkę Kraszewscy na Podlasiu (Wisznice 2013), będącą efektem kierowanego przez Profesora Czyżewskiego projektu naukowego poświęconego Kajetanowi Kraszewskiemu, realizowanego przez Bibliotekę Publiczną w Wisznicach. Projekt ten wpisywał się w obchody Roku Józe- 
fa Ignacego Kraszewskiego i miał na celu promocję lokalnego dziedzictwa kulturowego oraz rozwój tożsamości społeczności gminy wiejskiej Wisznice. Aby jednak ten obraz osiągnięć naukowych Profesora nieco urozmaicić, trzeba też powiedzieć, że Profesor nie tylko osobiście zajmował się problemami językowymi i kulturowymi tych ziem. Potrafił także zachęcić swoich uczniów do zainteresowania się ziemią włodawską, by przypomnieć choćby doktora habilitowanego Marka Olejnika i jego pracę Mikrotoponimia powiatu włodawskiego (Lublin 2014).

To tylko mały wyimek osiągnięć naukowych Profesora, które wiążą się $z$ terenami nadbużańskimi, ale wyimek pokazujący ogromne zaangażowanie dzisiejszego Jubilata w poznanie języka i kultury ziemi włodawskiej i szerzej - pogranicza polsko-wschodniosłowiańskiego oraz utrwalenie i upowszechnienie tej wiedzy daleko poza Lubelszczyzną. Ten aspekt działalności Profesora jest powszechnie znany i ceniony, także poza regionem i poza krajem. Profesor Bogdan Walczak w recenzji dorobku naukowego Feliksa Czyżewskiego w procedurze ubiegania się o tytuł naukowy profesora podsumował: „Dorobek naukowy kandydata do tytułu profesora jest z jednej strony różnorodny, a z drugiej - w wysokim stopniu spójny i homogeniczny - a to dzięki scalającej jego przeważną część nadrzędnej właściwości związku z domową ojczyzną badawczą - szeroko i wielorako rozumianym pograniczem polsko-wschodniosłowiańskim. Tematy i problemy badawcze podejmowane przez dra hab. Feliksa Czyżewskiego organicznie wynikają zarówno z przyjętej i zinterioryzowanej przez niego wizji języka, jak i z jego doświadczeń i obowiązków dydaktycznych oraz silnego poczucia służby swojej uczelni, miastu i regionowi. W jego twórczości naukowej harmonijnie się splata kilka nurtów i obszarów badawczych [...] Pod względem źródłowo-materiałowym wszystkie te nurty i obszary badawcze osadzone są na pograniczu polsko-wschodniosłowiańskim".

W ocenie środowisk akademickich Polski także inny aspekt działalności Profesora jest wartością niepodważalną - jest to opracowanie koncepcji i realizacja, najpierw przez Profesora, następnie z Jego inicjatywy przez młodszych Kolegów, transgranicznych konferencji naukowych, które są organizowane wspólnie przez Instytut Filologii Słowiańskiej uniwersytetu lubelskiego oraz lokalne władze samorządowe - Urząd Miejski we Włodawie i Urząd Gminy Wola Uhruska. W wielu tych sympozjach odbywających się we Włodawie bądź w pobliskiej Woli Uhruskiej uczestniczyłam i mogę powiedzieć, że są one absolutnie unikalne w skali całego kraju, przynajmniej jeśli chodzi o dyscyplinę, którą oboje z Profesorem reprezentujemy. Nie ma drugiego takiego w Polsce wydarzenia skupiającego językoznawców z różnych uczelni polskich, białoruskich i ukraińskich oraz lokalnych samorządowców, którzy w czasie wspólnych obrad przedstawiają i poddają pod dyskusję kwestie istotne dla miejscowych władz samorządowych i dla miejscowej społeczności, 
rysują perspektywy rozwoju tych ziem i słuchają naszych akademickich ocen i sugestii. W to wspólne dzieło włączają się także przedstawiciele dwóch największych na ziemi włodawskiej Kościołów - katolickiego i prawosławnego. Towarzyszą nam w tych wydarzeniach, włączają się do dyskusji, zwracają uwagę na problemy miejscowej społeczności. To wielkie dzieło Profesora Czyżewskiego. W tym miejscu myślą powracam do cytowanych wcześniej słów pana starosty włodawskiego, który podkreślał, że Profesor Czyżewski jest znakomitym „Ambasadorem Ziemi Włodawskiej”.

Słowa Pana Starosty są odzwierciedlone w przyznawanych Profesorowi wyróżnieniach, nagrodach, medalach. Jego wybitne osiągnięcia na niwie tak naukowej, jak i społecznej od lat są dostrzegane. Jest beneficjentem tak wielu nagród i odznaczeń, że trudno je wszystkie wymienić. Wspomnę więc tylko o nielicznych, subiektywnie przeze mnie wybranych.

Już w 1987 roku za swoją pierwszą monografię - Atlas gwar polskich i ukraińskich okolic Włodawy został wyróżniony, o czym już wspominałam, nagrodą indywidualną Ministra Nauki i Szkolnictwa Wyższego. W tym samym roku otrzymał prestiżowe Stypendium Ministra Oświaty Bułgarii, które umożliwiło Mu trzymiesięczny pobyt na Uniwersytecie Sofijskim, ale też było początkiem aktywności Profesora w zakresie promowania języka bułgarskiego i kultury Bułgarii na poziomie tak swojej macierzystej uczelni, jak i szkół średnich Lubelszczyzny. Działania te były wysoko oceniane przez Ministerstwo Oświaty, Młodzieży i Nauki Bułgarii, czego dowodem jest przyznanie Profesorowi honorowego wyróżnienia. Także Ministerstwo Spraw Zagranicznych Ukrainy doceniło Jubilata za wkład w polsko-ukraińską współpracę w dziedzinie oświaty, przyznając Mu honorowe wyróżnienie. Natomiast władze Rzeczypospolitej Polskiej, dostrzegając wielki wkład Profesora w rozwój polskiej nauki, dydaktyki, a także Jego ponadprzeciętną aktywność społeczną, przyznały Mu w 2013 roku Złoty Krzyż Zasługi i w 2015 roku Medal Komisji Edukacji Narodowej. W tym samym roku Ministerstwo Kultury i Dziedzictwa Narodowego przyznało Profesorowi, bardzo przez Niego cenioną, odznakę honorową „Zasłużony dla Kultury Polskiej”.

Profesor szczególnie sobie ceni wyróżnienia i nagrody za działalność w zakresie dokumentacji i popularyzacji kultury regionu lubelskiego. W roku 2004 jako redaktor i m.in. autor tekstów zamieszczonych w monografii pt. Gmina Wola Uhruska na tle Euroregionu Bug. Język i kultura otrzymał wyróżnienie honorowe w konkursie „Ludowe Oskary”, przyznane przez Stowarzyszenie Twórców Ludowych. Działania na rzecz Woli Uhruskiej spotkały się z uznaniem władz gminy, które w 2004 roku odznaczyły Profesora Medalem „800-lecie Uhruska”, a w 2007 roku za wkład w prace dokumentujące kulturę duchowa i materialna gminy Wola Uhruska dzisiejszy Jubilat został wyróżniony tytułem Honorowego Obywatela Gminy Wola Uhruska. Zaangażowanie Profesora w działalność popularyzatorską w powiecie włodawskim, 
a także Jego prace naukowe $\mathrm{z}$ zakresu dialektologii, oparte na materiałach terenowych z tego obszaru, zyskały uznanie członków i władz Towarzystwa Przyjaciół Ziemi Włodawskiej, które w 2009 roku wyróżniło Uczonego medalem „Zasłużony dla Towarzystwa Przyjaciół Ziemi Włodawskiej”. Z kolei aktywność naukowa Jubilata w zakresie badania języka inskrypcji nagrobnych, a także szersze działania podejmowane w ramach projektów związanych z nekropoliami pogranicza, mające wymiar ekumeniczny, spotkały się ze specjalnym uznaniem - w 2009 roku Święty Sobór Biskupów Świętego Polskiego Autokefalicznego Kościoła Prawosławnego przyznał Profesorowi Order Świętej Równej Apostołom Marii Magdaleny.

Aktywność Jubilata na rzecz regionu lubelskiego została doceniona także przez władze Lublina i województwa lubelskiego. Prezydent Lublina w 2012 roku w uznaniu zasług dla miasta odznaczył Go Medalem Prezydenta Miasta Lublina. W roku 2013 zaś otrzymał z rąk Prezydenta Lublina nagrodę specjalną wraz z Medalem „Civitatis Lublinensis” za zasługi na rzecz upowszechniania kultury polskiej za granicą, a w 2016 roku został uhonorowany przez Marszałka Województwa Lubelskiego nagrodą z okazji jubileuszu 40-lecia działalności kulturalnej.

Dzisiaj przyszedł czas na szczególne i ważne w życiorysie Profesora Czyżewskiego uhonorowanie, na przyznanie Mu tytułu Honorowy Obywatel Włodawy. Dlatego w zakończeniu tych kilku refleksji pragnę raz jeszcze podziękować władzom miasta za to, że właśnie wybitnego uczonego, językoznawcę, który dużą część swego życia poświęcił, by utrwalić i rozsławić wyjątkową ziemię włodawską, gdzie spotykają się różne etnosy, kultury i języki, wyróżniły tak zaszczytnym tytułem. Dla tego regionu bowiem ów Wybitny Humanista zrobił wiele. Wielki szacunek dla władz lokalnych za docenienie Jego wysiłku. Na tytuł ten zasłużył sobie z naddatkiem.

Dostojny Jubilacie, Wielce Szanowny Panie Profesorze, proszę przyjąć z tej okazji najszczersze gratulacje, a z okazji 70. rocznicy urodzin - życzenia dalszych długich lat w dobrym zdrowiu, wśród kochającej i oddanej Rodziny, wśród przyjaznych ludzi, w pełnej aktywności zawodowej i w działaniach społecznych. To ostatnie życzenie jest też życzeniem dla społeczności ziemi włodawskiej, która czeka na dalsze Twoje zainteresowanie, na aktywność równą dotychczasowej. Bądź aktywny, bo: jak długo jesteśmy aktywni, tak długo jesteśmy młodzi.

\section{Ad multos annos, Szanowny i Drogi Jubilacie!}


